\title{
Controversial Nutrients That Potentially Affect Preterm Neurodevelopment: Essential Fatty Acids and Iron
}

\author{
MICHAEL K. GEORGIEFF AND SHEILA M. INNIS \\ University of Minnesota School of Medicine [M.K.G.], 420 Delaware St. SE, Minneapolis, MN USA \\ 55455; Nutrition Research Program [S.I.M.], B.C. Research Institute, Professor, Department of \\ Pediatrics, University of British Columbia, Vancouver, BC V5Z 4H4, Canada
}

\begin{abstract}
Although all nutrients are needed for normal fetal and postnatal development, small preterm infants are particularly susceptible to nutrient deficiencies. The potential for immediate and long-term consequences of deficiency varies among nutrients. Essential fatty acids and iron are of particular interest because both are commonly deficient in the preterm infant, excessive or inadequate intakes are both of concern, and both are crucial to normal CNS development with the potential for long lasting effects that extend beyond the period of dietary insufficiency. Although seemingly diverse in physiologic roles, advances in the understanding of iron and essential fatty acid metabolism provide an exemplary illustration how different nutrients interact to support normal growth and development.
\end{abstract}

The potential for adverse effect of inadequate or excess intake of any nutrient on any organ system is based on the timing, dose and duration of exposure (1). The vulnerability of a particular organ thus depends on the concurrence of two factors; the presence of a critical (or sensitive) period of growth and development that is dependent on the nutrient in question; and deficiency of the nutrient in the population at the time of this sensitive period. Effects that last beyond the period of exposure result from deviations from the normal developmental trajectory, involving morphologic process for example neuritogenesis, myelination, expression of genes for key proteins or endocrine factors that regulate development, that are incompletely recovered at some later stage with restoration of normal nutrition. The brain between 6 mo postconception and $1 \mathrm{y}$ of age undergoes a remarkable transformation from a relatively primitive, poorly sulcated and gyrated structure into a complex, integrated organ. Important neurodevelopmental processes at this time include the onset of myelination, organization of neurotransmitter systems, dendritic arborization and selective pruning, and synaptogenesis particularly in the visual system and the hippocampus (Fig. 1) (2). Iron and essential fatty acids impact on these developmental processes at multiple levels that have the potential for lasting effects in preterm infants inadequately nourished with these nutrients.

Received December 15, 2004; accepted February 1, 2005

Correspondence: Michael K. Georgieff, M.D., Professor of Pediatrics, University of Minnesota School of Medicine, Minneapolis, MN 55455; E-mail: Georg001@umn.edu

\section{ESSENTIAL FATTY ACID REQUIREMENTS OF THE PRETERM INFANT}

Docosahexaenoic acid (DHA, 22:6n-3) and arachidonic acid (ARA, 20:4n-6) are required by preterm infants to support growth and development. DHA and ARA are formed from the essential fatty acids, linoleic acid (LA, 18:2n-6) and $\alpha$-linolenic acid (LNA,18:3n-3), respectively, by elongation and desaturation (3) and are the major polyunsaturated fatty acids in fetal plasma. In contrast, LA and LNA are the most abundant $n-6$ and n-3 fatty acids in human milk, infant formula and IV lipids. Plasma LA increases, while ARA and DHA decrease rapidly with the initiation of feeding. LA and LNA are mutually competitive and their metabolism is inhibited by products of the autologous and opposing fatty acid series (4). Thus, inappropriately high intakes of one of the n- 6 and n-3 fatty acids can have deleterious effects on other n-6 and n-3 fatty acids. DHA and ARA are present in membrane phospholipids where they regulate membrane functions, and from which they are released to act directly or as precursors to molecules that modulate cell growth, inter- and intra-cellular communication and protein function (3). DHA is selectively accumulated in specific tissues that include the retina and brain grey matter. Depletion of DHA from the brain and retina results in reduced visual function, cognitive and behavioral abnormalities, altered monaminergic neurotransmitter metabolism, and decreased membrane protein and receptor activities (3). The monoamines dopamine and serotonin are important in many of the cognitive and behavior advances of early childhood; their synthesis is regulated by the iron dependent tyrosine and tryptophan hydroxylase, respectively. ARA is found in membranes throughout the body, fulfills the role of n- 6 fatty acids in growth, and is the precursor for eicosanoids and other signal molecules. N-6 and n-3 fatty acids also regulate carbohydrate and lipid metabolism through effects on gene expression involving steroid regulatory element binding proteins and peroxisomal proliferator activated receptors $(3,5,6)$. The desaturases required for synthesis of ARA and DHA, and delta 9 desaturase required for synthesis of oleic acid (18) (which is the major monoenoic fatty acid in brain white and grey matter), are iron dependent enzymes.

Essential fatty acids in the fetus and preterm infant. The higher ARA and DHA and lower LA in fetal, (rather than maternal or infant) plasma $(7,8)$ maybe explained in part by 


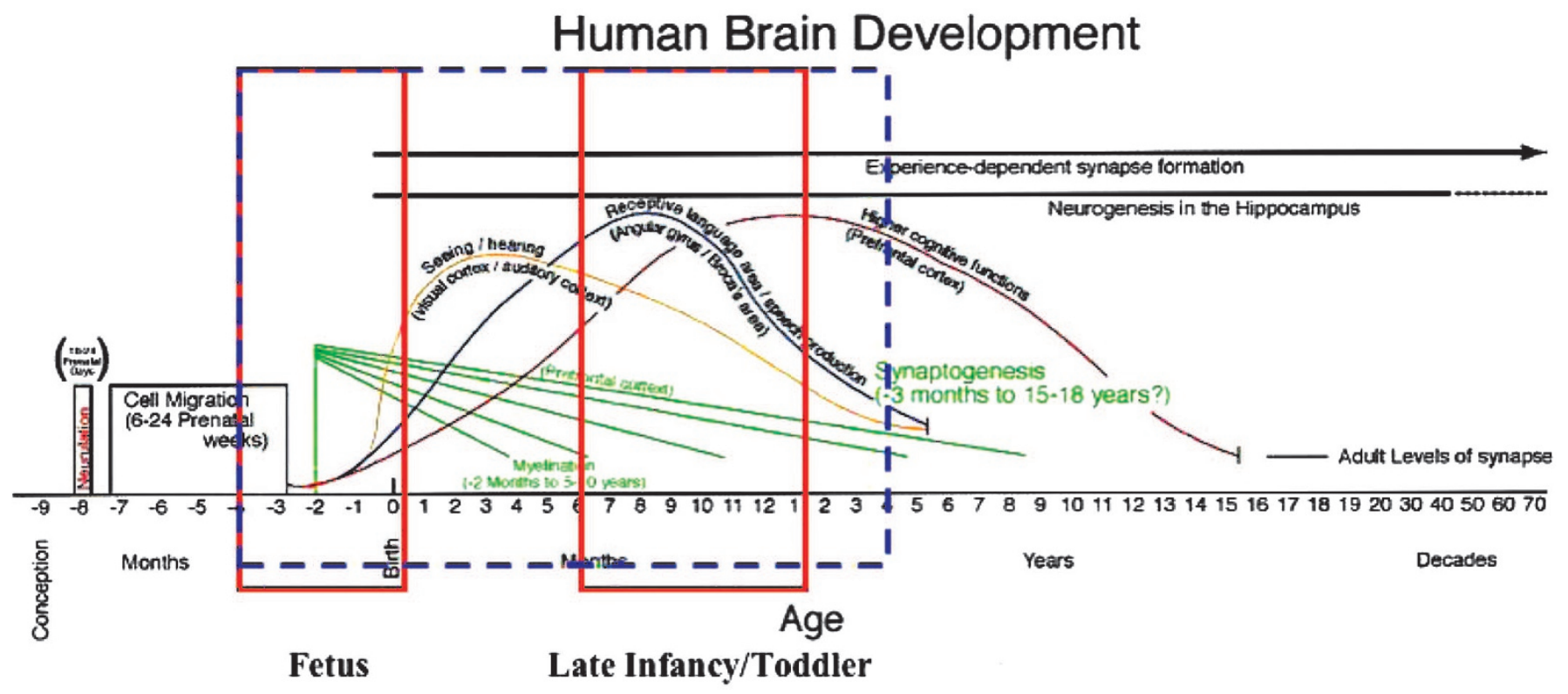

Figure 1. Risk periods for alterations in essential fatty acid (blue box) and iron (red boxes) metabolism during early human brain development. Brain development chart adapted from reference 2 .

placental fatty acid binding and transport proteins that favor transfer of ARA and DHA $(8,9)$. Other differences in plasma lipids before and after birth include the high ARA in fetal cholesterol esters, presence of high-density lipoprotein (HDL) as a major lipoprotein, low chylomicrons and very low-density lipoprotein (VLDL), and transport of ARA and DHA by $\alpha$-fetoprotein (8). Whether the low LA relative to ARA and DHA is fetal plasma is important in facilitating optimal tissue delivery of these fatty acids is unclear. However, the possibility that high LA may inhibit tissue DHA accumulation has been raised $(8,10)$.

LA and LNA are the major n- 6 and n- 3 fatty acids in human milk fat (mean 12\% LA, 1.4\% LNA, 0.4\% ARA, 0.2\% DHA), formula (16-20\% LA, 1,5-2.3\% LNA, 0.4-0.6\% ARA, 0.2$0.3 \%$ DHA) and IV lipids (53\% LA, 7\% LNA, 0.2\% ARA, $0.2 \%$ DHA in $20 \mathrm{~g} / \mathrm{dL}$ soybean triglyceride emulsions containing egg phospholipid) $(11,12)$. The desaturation of LNA to DHA in humans, including infants, is low with $<1 \%$ to $9 \%$ of a dose of isotopically labeled LNA converted to DHA (13). However, LNA conversion appears to be at least as high in preterm as term infants (14). Increasing the LNA content of formula has little effect in increasing blood lipid DHA, but feeding with ARA or DHA is efficacious in increasing blood and tissue ARA and DHA, respectively $(10,15,16)$. Thus, DHA is clearly more efficacious for tissue DHA accretion than the LNA precursor $(17,18)$. There is no evidence that infants are unable to form adequate ARA, except possibly following eicosapentaenoic acid (EPA, 20:5n-3) and DHA supplementation which could antagonize ARA synthesis or acylation.

Studies with preterm infants supplemented with ARA and DHA. Several sources of DHA (fish oils, egg lipids and single cell (algal) oil), and ARA (egg lipids and single cell (fungal) oil), have been considered for addition to infant formula. Early studies found evidence of reduced growth and lower peripheral nerve conduction velocities in preterm infants fed formula with
DHA without ARA (19-22). The lower growth was presumed to be due to suppression of ARA by EPA and/or DHA. Subsequent studies have not found lower growth in infants fed formulas with both DHA and ARA $(16,23,24)$. Rather, higher growth in preterm infants fed formula with ARA and DHA from single cell oils and a positive relation between plasma ARA and preterm infant growth has been shown $(16,25)$. A recent study has noted lower growth at 18 mo of age in preterm infants fed formula with $0.4 \% \gamma$ linolenic acid (18:3n-6), $0.3 \%$ ARA and $0.17 \%$ DHA from egg lipids, which included cholesterol (26). These findings suggest different sources of ARA and DHA can differ in their effects on preterm infant growth and development.

Several studies concur that dietary DHA increases the early development of visual acuity in preterm infants $(23,27)$. An advantage in tests of mental and language development has also been reported in small preterm infants $<1,250 \mathrm{~g}$ birthweight fed formula with DHA and ARA (23). The improved visual and neural development in the latter studies show that $1.2 \%$ energy as LNA present in the unsupplemented formula does not meet the n-3 fatty acid requirements of preterm infants.

Essential fatty acid requirements. One approach to address the nutrient needs of preterm infants is to match the plasma nutrient levels of the fetus. However, fetal plasma is characterized by low VLDL and LDL, low LA and high ARA and DHA (8). Human milk, infant formula, or IV lipids are provided to attain growth rates approaching that of the third trimester fetus, and triglyceride-rich lipoproteins high LA emerge as a major plasma lipid transport particle. Feeding with triglycerides high in LA as a major energy source make it unlikely that plasma ARA and DHA levels similar to the third trimester fetus can be achieved in parenterally or enterally fed infants. 
Alternatively, an estimate of needs can be derived from estimates of fatty acid accretion in fetal tissue. Autopsy tissue analyses have estimated an accretion of $552 \mathrm{mg} / \mathrm{d} \mathrm{n}-6$ fatty acids and $67 \mathrm{mg} / \mathrm{d} \mathrm{n}-3$ fatty acids during the last trimester of gestation (28). Most of the $\mathrm{n}-3$ fatty acids accumulated is DHA, while fetal liver and adipose tissue contain about 2-fold more ARA than LA (29). Fetal brain accretion has been estimated as $5.8 \mathrm{mg} \mathrm{n}-6$ and $3.1 \mathrm{mg} \mathrm{n}-3$ fatty acids/d, representing about $1.1 \%$ and $4.65 \%$ total body accretion. It is not known if the fetal brain is protected during limited DHA availability; however, prenatal n-3 fatty acid deprivation does result in a large deficit in fetal brain DHA in animals (30). Estimation of the essential fatty acid intakes of preterm infants fed at $120 \mathrm{~mL} / \mathrm{kg}$ with human milk or formula, or given IV lipid (Table 1) shows the marked overabundance of LA and LNA compared with the estimated fetal accretion. Assuming 5\% or 10\% LNA is converted to DHA, a theoretical estimate of the total potential DHA available from $120 \mathrm{~mL} / \mathrm{kg} / \mathrm{d}$ milk or formula, or $3 \mathrm{~g} / \mathrm{kg} / \mathrm{d}$ IV lipid is $11-28 \mathrm{mg}$ DHA, which is less than $50 \%$ of the estimated in utero accretion of $60 \mathrm{mg} / \mathrm{d}$. Although these estimates are based on limited data, and growth and tissue DHA accretion are not linear, it is apparent that current approaches to lipid nutrition for preterm infants are likely to result in marked differences in tissue fatty acids from that achieved in utero.

\section{IRON AND BRAIN DEVELOPMENT}

Iron deficiency potentially affects multiple developmental brain processes including myelination (31), monoamine metabolism (32), energy metabolism (33), and hippocampal dendritic growth (34), most of which are dependent on ironcontaining hemoproteins or iron-sulfur compounds that are compromised by iron deficiency. The effect on myelination (31) is due in part to effects on iron-dependent enzymes in fatty acid synthesis pathways (35) and oligodendrocyte function (31). Hypomyelination would be expected lead to slower nerve conduction velocity, an effect manifested in 6-mo-old human infants by abnormal auditory brainstem evoked responses while iron deficient (36) and following iron repletion (37). Early iron deficiency in the rat results in reduced hippocampal cytochrome $c$ (a hemoprotein) concentrations and cytochrome $c$ oxidase activity, thus altering energy utilization in a brain region that subserves recognition memory. Iron deficient human neonates show electrophysiologic evidence of reduced recognition memory at birth while iron deficient (38) and following iron repletion (39). Early iron deficiency in rats also has profound effects on the developing dopaminergic system particularly in the basal ganglia, a brain region that subserves procedural memory and motor function (40). In humans, early postnatal iron deficiency alters motor movement patterns while infants are iron deficient and long-term striatal-frontal cognitive functions $(41,42)$. Ultimately, the integration of all these negative brain effects compromise later integrated cognitive performance (41). For example, infants born with cord serum ferritins in the lowest quartile have poorer school performance than those in the middle quartiles (43).

Several common pathologic conditions during gestation affect newborn brain iron status. These include severe maternal iron deficiency, intrauterine growth-retardation due to maternal hypertension, premature delivery and gestational or pregestational maternal diabetes mellitus. The first three result in decreased iron delivery to the fetus while the latter results in decreased delivery and a redistribution of iron into the red cell mass (and away from the brain) within the fetus $(44,45)$. Fetal iron status will be compromised when the mother's $\mathrm{Hb}$ concentration is less than $85 \mathrm{~g} / \mathrm{L}$, although recent evidence suggests that alterations in iron metabolism occur at $\mathrm{Hb}$ concentrations as high as $105 \mathrm{~g} / \mathrm{L}$ (46). Although profound maternal iron deficiency is relatively rare in developed nations, the worldwide rate approaches 30 to 50\%. Decreased placental function due to maternal hypertension results in intrauterine growth retardation and iron deficiency. Fifty percent of growth retarded infants have newborn serum ferritin concentrations below the 5th percentile $(<60 \mu \mathrm{g} / \mathrm{L})$ (47). A conservative estimate would predict that 75,000 infants per year are affected in the United States. At autopsy, intrauterine growth retardation (IUGR) infants have a $33 \%$ reduction in brain iron (48). In pregnancies complicated by diabetes, the degree of maternal glucose intolerance drives the degree of iron deficiency $(44,45)$. Fetal hyperglycemia and hyperinsulinemia increase fetal oxygen consumption by 15 to $30 \%(49,50)$, rendering the fetus chronically hypoxemic and stimulating compensatory erythropoiesis (51). The human (and sheep) placenta do not appear to compensate for the increased iron need for this augmented erythropoiesis (52), forcing the fetus to prioritize available iron to the red cell mass over the brain $(44,45,53)$. Up to $65 \%$ of infants of diabetic mothers $(150,000$ newborns/y in the US) are affected. At autopsy, IDMs (infants of diabetic mothers) have a $40 \%$ reduction of brain iron content (44).

Table 1. Estimated intake of essential fatty acids from human milk, infant formula or intravenous lipids in the preterm infant

\begin{tabular}{|c|c|c|c|c|c|c|}
\hline & \multirow{2}{*}{$\begin{array}{l}\text { Human milk* } \\
120 \mathrm{~mL} / \mathrm{kg} / \text { day }\end{array}$} & \multirow{2}{*}{$\begin{array}{l}\text { Preterm formula** } \\
120 \mathrm{~mL} / \mathrm{kg} / \mathrm{day}\end{array}$} & \multicolumn{3}{|c|}{ I.V. Lipid† } & \multirow[b]{2}{*}{ Intrauterine $\ddagger$} \\
\hline & & & $0.5 \mathrm{~g} / \mathrm{kg}$ & $1.0 \mathrm{~g} / \mathrm{kg}$ & $3.0 \mathrm{~g} / \mathrm{kg}$ & \\
\hline LA $(18: 2 n-6)$ & 530 & $710-880$ & 265 & 530 & 1590 & 184 \\
\hline LNA (18:3n-3) & 60 & $71-98$ & 36 & 72 & 216 & 7 \\
\hline DHA $(22: 6 n-3)$ & 8 & $8-16$ & 1 & 2 & 6 & 60 \\
\hline$\Sigma$ DHA + LNA equivalent§ & $(11-14)$ & $(12-25)$ & $(2.8-4.6)$ & $(5.6-9.4)$ & $(18-28)$ & \\
\hline
\end{tabular}

* Based on 12\% LA, 1.4\% LNA, 0.7 ARA, 0.2\% DHA and $3.7 \mathrm{~g}$ fat/dL milk (11).

** Range represents preterm formula with $16-20 \%$ LA, $1.6-2.2 \%$ LNA, $0.4-0.6 \%$ ARA, $0.2-0.4 \%$ DHA.

$\dagger 100 \%$ soybean oil in a $20 \%$ emulsion with egg phospholipid as emulsifier (18).

$\ddagger$ Intrauterine estimate assumes tissue ARA twofold higher than LA and DHA equivalent to $90 \%$ of total n-3 fatty acids $(28,29)$.

$\S$ Estimated total potential DHA, assuming 5-10\% LNA converted to DHA. 
There is evidence that IDMs and IUGRs have altered short and long-term neurologic processing $(38,39,54,55)$.

Prematurity places the developing brain at risk for iron deficiency and iron overload. The fetus accretes iron primarily during the last trimester of pregnancy. Infants born prematurely have lower total body iron contents than those born at term. After birth, factors that lead to negative iron balance include phlebotomy, a rapid catch-up growth rate that necessitates equally rapid expansion of the red cell mass, more conservative transfusion practices (and the use of recombinant human erythropoietin), and human milk feeding without iron supplementation (56). Iron deficiency is common and occurs earlier in the postdischarge period in preterm infants (57), a finding that prompted the recommendation that preterm infants be supplemented with $2-4 \mathrm{mg} / \mathrm{kg} / \mathrm{d}$ of iron beginning as early as 2 wk and no later than 2 mo of postnatal life (58). It remains controversial whether premature infants in the newborn intensive care unit are iron deficient. Recent studies have shown elevated zinc protoporphyrin/heme ratios in predischarge premature infants who are rapidly growing $(59,60)$, suggesting that iron availability is limiting the ability of these infants to synthesize $\mathrm{Hb}$. A recent study also demonstrates that preterm infants with ferritin concentrations in the lowest quartile at the end of their neo-natal intensive care unit hospitalization have an increased rate of abnormal neurologic reflexes (61). Although it remains to be determined whether these changes in brain function are long-lasting, this study is the first to link iron deficiency and abnormal neurodevelopment in this population.

Finally, one must consider the potential neurologic hazards of iron overload in preterm infants. While it is clear that iron potentially plays a large role in reperfusion injuries following birth asphyxia (62), the role of nutritional iron in brain injury in humans remains unproven. Nevertheless, the premature infant's brain may be at high risk for iron overload because of serum iron binding capacity, immature anti-oxidant systems and rapidly growing tissues and the exposure to IV iron and multiple red cell transfusions (63). No study has convincingly demonstrated that nutritional iron overload contributes to adverse neurodevelopment in preterm infants.

\section{CONCLUSION}

This review has highlighted recent advances in the biology of the long chain polyunsaturated fatty acids, particularly DHA, and iron. Both DHA and iron are required for normal biochemical and functional development of the CNS. When imposed at critical periods of development, deficiency of DHA or iron results in deficits in monoamine metabolism $(17,30,32)$, and decreased performance on tests of cognitive performance $(19,38,41,43)$; both nutrients are also involved in normal membrane lipid biosynthesis including myelination $(31,35,64)$. In animal models, iron deficiency and n-3 fatty acid deficiency have been studied in isolation; although in clinical practice, small preterm infants are frequently compromised with respect to nutrition with both these nutrients. The essential role of iron in fatty acid desaturation and monoamine synthesis raise questions of whether or not iron deficiency further compounds the adverse effects of poor DHA and ARA status on the growth and development of preterm infants. DHA and ARA are found only in animal tissues, which also provide heme iron. The greater bioavailability of heme than nonheme iron and efficacy of dietary DHA compared with its LNA precursor which, like nonheme iron, is present in plant foods, raise additional research questions on the co-morbidity of inadequate DHA and iron in many of the world's children.

\section{REFERENCES}

1. Kretchmer N, Beard JL, Carlson S 1996 The role of nutrition in the development of normal cognition. Am J of Clin Nutr 63:977-1001

2. Thompson RA, Nelson CA 2001 Developmental science and the media: Early brain development. American Psychologist 56(1):5-15

3. Innis SM 2003 Perinatal biochemistry and physiology of long chain polyunsaturated fatty acids. J Pediatr 143:S1-S8

4. Innis SM 1991 Essential fatty acids in growth and development. Prog Lipid Res 30:39-103

5. Jump DB 2004 Fatty acid regulation of gene transcription. Crit Rev Clin Lab Sci 41:4178

6. Sampath H, Ntambi JM 2004 Polyunsaturated fatty acid regulation of gene expression. Nutr Rev 62:333-339

7. Elias SL, Innis SM 2001 Newborn infant plasma trans, conjugated linoleic, n-6 and n-3 fatty acids are related to maternal plasma fatty acids, length of gestation and birth weight and length. Am J Clin Nutr 73:807-814

8. Innis SM 2005 Essential fatty acid transfer and fetal development. Placenta, in press

9. Dutta-Roy AK 2000 Transport mechanisms for long-chain polyunsaturated fatty acids in the human placenta. Am J Clin Nutr 71:315S-332S

10. Innis SM, Auestad N, Siegman JS 1996 Blood lipid docosahexaenoic acid, low eicosapentaenoic acid fish oil. Lipids 31:617-625

11. Innis SM, King DJ 1999 Trans fatty acids in human milk are inversely associated with levels of essential all-cis n- 6 and n-3 fatty acids, and determine trans, but not n- 6 and n-3 fatty acids in plasma of breast-fed infants. Am J Clin Nutr 70:383-390

12. Morris S, Simm K, Gibson R 2000 Utilization of docosahexaenoic acid from intravenous egg phospholipid. Lipids 35:383-388

13. Burdge G 2004 Alpha linolenic acid metabolism in men and women: nutritional and biological implications. Curr Opin Nutr Metab Care 7:137-144

14. Uauy R, Mena P, Wegher B, Nieto S, Salem N Jr 2000 Long chain polyunsaturated fatty acid formation in neonates, effect of gestational age and intrauterine growth. Pediatr Res 47:127-135

15. Ponder DL, Innis SM, Benson JD, Siegman JS 1992 Docosahexaenoic acid status of term infants fed breast milk or infant formula containing soy oil or corn oil. Pediatr Res 32:683-688

16. Innis SM, Adamkin DH, Hall RT, Kalhan SC, Lair C, Lim M, Stevens DC, Twist PF, Diersen-Schade DA, Harris CL, Merkel KL, Hansen JW 2002 Docosahexaenoic acid and arachidonic acid enhance growth with no adverse effects in preterm infants fed formula. J Pediatr 140:547-554

17. de la Presa Owens, Innis SM 1999 Docosahexaenoic and arachidonic acid reverse changes in dopaminergic and serotoninergic neurotransmitters in piglet frontal cortex caused by a linoleic and alpha linolenic acid deficient diet. J Nutr 129:2088-2093

18. Su HM, Bernardo M, Mirmiran XH, Ma TN, Corso PW, Nathanielsz JT, Brenna JT 1999 Bioequivalence of dietary $\alpha$-linolenate and docosahexaenoate acids as possible sources of docosahexaenoate accretion in brain and associated organs of neonatal baboons. Pediatr Res 45:87-93

19. Bougle D, Denise P, Vimard F, Nouvelot A, Penncillo MJ, Guillois B 1999 Early neurological and neurophysical development of the preterm infant and polyunsaturated fatty acid supply. Clin Neurophysiol 110:1363-1370

20. Carlson DE, Cooke RJ, Werkman SH, Tolley EA 1992 First year growth of infants fed standard formula compared with marine oil supplemented formula. Lipids 27:901-907

21. Carlson SE, Werkman SH, Tolley EA 1996 Effect of long-chain n-3 fatty acid supplementation on visual acuity and growth of preterm infants with and without bronchopulmonary dysplasia. Am J Clin Nutr 63:687-697

22. Ryan AS, Montalto MB, Groh-Wargo S, Mimouni F, Sertipal-Walerius J, Doyle J, Siegman JS, Thomas AJ 1999 Effect of DHA-containing formula in growth of preterm infants to 59 weeks postmenstrual age. Am J Hum Biol 11:457-467

23. O'Connor DL, Auestad N, Jacobs J 2001 Growth and development in preterm infants fed long-chain polyunsaturated fatty acids, a prospective randomized controlled trial. Pediatrics 108:359-372

24. Simmer K 2000 Long-chain polyunsaturated fatty acid supplementation in preterm infants (Cochrane Review). Cochrane Data Base Syst Rev 3:CD000376

25. Carlson SE, Werkman SH, Peeples JM, Cooke RJ, Tolley EA 1993 Arachidonic acid status correlates with first year growth in preterm infants. Proc Natl Acad Sci 90:1073-1077

26. Fewtrell MS, Morley R, Abbott RA, Singhal A, Issacs EB, Stephenson T, MacFayden U, Lucas A 2002 Double-blind randomized trial of long-chain polyunsaturated fatty acid supplementation in formula fed to preterm infants. Pediatrics 110:73-82

27. San Giovanni JP, Parra-Cabrera S, Colditz GA, Berkey CS, Dwyer JT 2000 Metaanalysis of dietary essential fatty acids and long-chain polyunsaturated fatty acids as they relate to visual resolution acuity in healthy preterm infants. Pediatrics 105:12921298 
28. Clandinin MT, Chappell JE, Heim T, Swyer PR, Chance GW 1981 Fatty acid utilization in perinatal de novo synthesis of tissues. Early Human Dev 5:355-366

29. Clandinin MT, Chappelll JE, Heim T, Swyer PR, Chance GW 1981 Fatty acid accretion in fetal and neonatal liver: implications for fatty acid requirements. Early Human Dev 5:7-14

30. Innis SM, de La Presa Owens S 2001 Dietary fatty acid composition in pregnancy alters neurite membrane fatty acids and dopamine in newborn rat brain. J Nutr 131:118-122

31. Connor JR, Menzies SL 1990 Altered cellular distribution of iron in the central nervous system of myelin deficient rats. Neuroscience 34:265-271

32. Chen Q, Beard JL, Jones BC 1995 Abnormal rat brain monoamine metabolism in iron deficiency anemia. J Nutr Biochem 6:486-493

33. deUngria M, Rao R, Wobken JD, Luciana M, Nelson CA, Georgieff MK 2000 Perinatal iron deficiency decreases cytochrome c oxidase (cytox) activity in selected regions of neonatal rat brain. Pediatr Res 48:169-176

34. Jorgenson LA, Wobken JD, Georgieff MK 2003 Perinatal iron deficiency alters apical dendritic growth in hippocampal CA-1 pyramidal neurons. Developmental Neuroscience 25:412-420

35. Yu GSM, Steinkirchner TM, Rao GA, Larkin EC 1986 Effect of prenatal iron deficiency on myelination in rat pups. Am J Pathol 125:620-624

36. Roncagliolo M, Garrido M, Walter T, Peirano P, Lozoff B 1998 Evidence of altered central nervous system development in infants with iron deficiency anemia at 6 months: delayed maturation of auditory brainstem responses. Am J Clin Nutr 68:683-690

37. Algarin C, Peirano P, Garrido M, Pizarro F, Lozoff B 2003 Iron deficiency anemia: long-lasting effects on auditory and visual system functioning. Pediatr Res 53:217223

38. Siddappa AJM, Georgieff MK, Wewerka S, Worwa C, Nelson CA, deRegnier R-A 2004 Iron deficiency alteres auditory recognition memory in newborn infants of diabetic mothers. Pediatric Research 55:1034-1041

39. Nelson CA, Wewerka SS, Borscheid AJ, deRegnier RA, Georgieff MK 2003 Electrophysiologic evidence of impaired cross-modal recognition memory in 8-month-old infants of diabetic mothers. J Pediatr 142:575-582

40. Beard JL, Connor JR 2003 Iron status and neural functioning. Annu Rev Nutr 23:41-58

41. Lozoff B, Jimenez E, Hagen J, Mollen E, Wolf AW 2000 Poorer behavioral and developmental outcome more than 10 years after treatment for iron deficiency in infancy. Pediatrics 105:852-858

42. Angulo-Kinzler RM, Peirano P, Lin E, Garrido M, Lozoff B 2002 Spontaneous motor activity in human infants with iron-deficiency anemia. Early Hum Dev 66:67-79

43. Tamura T, Goldenberg RL, Hou J, Johnston KE, Cliver SP, Ramey SL, Nelson KG 2002 Cord serum ferritin concentrations and mental and psychomotor development of children at five years of age. J Pediatr 2:165-170

44. Petry CD, Eaton MA, Wobken JD, Mills MM, Johnson DE, Georgieff MK 1992 Iron deficiency of liver, heart, and brain in newborn infants of diabetic mothers. J Pediatr 121:109-114

45. Georgieff MK, Landon MB, Mills MM, Hedlund BE, Faassen AE, Schmidt RL, Ophoven JJ, Widness JA 1990 Abnormal iron distribution in infants of diabetic mothers: spectrum and maternal antecedents. J Pediatr 117:455-461

46. O'Brien KO, Zavaleta N, Abrams SA, Caulfield LE 2003 Maternal iron status influences iron transfer to the fetus during the third trimester of pregnancy. Am J Clin Nutr 77:924-930
47. Chockalingam UM, Murphy E, Ophoven JC, Weisdorf SA, Georgieff MK 1987 Cord transferrin and ferritin levels in newborn infants at risk for prenatal uteroplacental insufficiency and chronic hypoxia. J Pediatr 111:283-286

48. Georgieff MK, Petry CE, Wobken JD, Oyer CE 1996 Liver and brain iron deficiency in newborn infants with bilateral renal agenesis (Potter's syndrome). Pediatr Pathol 16:509-519

49. Milley JR, Papacostas JS, Tabata BK 1986 Effect of insulin on uptake of metabolic substrates by the sheep fetus. Am J Physiol 251:E349-359

50. Phillips AF, Porte PJ, Strabinsky S, Rosenkranz TS, Raye JR 1984 Effects of chronic fetal hyperglycemia upon oxygen consumption in the ovine uterus and conceptus. J Clin Invest 74:279-286

51. Widness JA, Susa JB, Garcia JF, Singer DB, Seghal P, Oh W, Schwartz R, Schwartz HC 1981 Increased erythropoiesis and elevated erythropoietin in infants born to diabetic mothers and in hyperinsulinemic rhesus fetuses. J Clin Invest 67:637-642

52. Petry CD, Eaton MA, Wobken JD, Seybold VS, Johnson DE, Georgieff MK1994 Placental transferrin receptor localization and binding characteristics in diabetic pregnancies characterized by increased fetal iron demand. Am J Physiol 267 (Endocrinol Metab 30):E507-E514

53. Georgieff MK, Schmidt RL, Mills MM, Radmer WJ, Widness JA 1992 Fetal iron and cytochrome $\mathrm{c}$ status after intrauterine hypoxemia and erythropoietin administration. Am J Physiol 262:R485-R491

54. Black LS, deRegnier RA, Long L, Georgieff MK, Nelson CA 2004 Electrographic imaging of recognition memory in 34-38 week gestation intrauterine growth restricted newborns. Experimental Neurology 190:S72-S83

55. Rizzo TA, Dooley SL, Metzer BE, Cho NH, Ogata ES, Silverman BC 1995 Prenatal and perinatal influences on longterm psychomotor development in offspring of diabetic mothers. Am J Obstet Gynaecol 173:1753-1758

56. Rao R, Georgieff MK 2002 Perinatal aspects of iron metabolism. Acta Paediatrica 38(Suppl):124-129

57. Hall RT, Wheeler RE, Benson J, Harris G, Rippetoe L 1993 Feeding iron-fortified premature formula during initial hospitalization to infants less than 1800 grams birth weight. Pediatrics 92:409-414

58. American Academy of Pediatrics. Committee on Nutrition 1998 Nutritional needs of preterm infants. In: Kleinman RE, ed. Pediatric nutrition handbook. American Academy of Pediatrics, Elk Grove Village, IL, pp 55-87

59. Winzerling JJ, Kling PJ 2001 Iron-deficient erythropoiesis in premature infant measured by blood zinc protoporphyrin/heme. J. Pediatr 139:134-136

60. Juul SE, Zerzan JC, Strandjord TP, Woodrum DE 2003 Zinc protoporphyrin/heme as an indicator of iron status in NICU patients. J Pediatr 142:273-278

61. Armony-Sivan R, Eidelman A, Lanir A, Sredni D, Yehuda S 2004 Iron status and neurobehavioral development of premature infants. J Perinatol 24:757-762

62. Palmer C, Roberts RL, Bero C 1994 Deferoxamine posttreatment reduces ischemic brain injury in neonatal rats. Stroke 25:1039-1045

63. Pollak A, Hayde M, Hayn M, Herkner K, Lombard KA, Lubec G 2000 Effect of intravenous iron supplementation on erythropoiesis in erythropoietin treated premature infants. Pediatrics 107:78-85

64. Martinez M, Vazquez, E 1998 MRI evidence that docasahexaenoic acid ethyl ester improves myelination in generalized peroxisomal disorders. Neurology 51:26-32 